\title{
Characterization of variants of Bradyrhizobium elkanii and B. japonicum and symbiotic behaviour in soybeans
}

\author{
Caracterização de variantes de estirpes de Bradyrhizobium elkanii and B. japonicum e comportamento \\ simbiótico em soja
}

Marcia de Vargas Kober ${ }^{1}$ Enilson Luiz Saccol de Sá ${ }^{2}$ João Ruy Jardim Freire² Adriana Giongo $^{3}$

\begin{abstract}
Variation in rhizobia strains isn't a desirable fact based mainly on the possibility of unexpected results on legume inoculation. In this work, we studied the variability on phenotypic characteristics and genetic stability of rhizobia strains recommended for soybean inoculation. Variants with stable colony morphology were obtained from Bradyrhizobium japonicum strain SEMIA 5080 and from $\boldsymbol{B}$. elkanii SEMIA 5019. Variants from SEMIA 587 obtained by another author were also used. The variants differed on colony characteristics, nodulation capacity, nitrogen fixation efficiency and competitive ability for nodule formation in two soybean varieties (Jacui 7 and IAS 5). Symbiotic behavior varied according to plant variety. Only the variants $5019 \mathrm{G}$ and $5019 P$ differed on the isoenzymatic profile. There were differences in antibiotic resistance between variants from two strains. Correlation between symbiotic characteristics and colony morphology or antibiotic resistance wasn't conclusive. The results indicate that the variability in rhizobia strains might be an important factor to be considered in strain selection and preservation of cultures for inoculant production.
\end{abstract}

Key words: variants isolation, inoculant production, isoenzymes.

\section{RESUMO}

Variantes em estirpes de rizóbio usadas na produção de inoculantes não são desejáveis e podem propiciar resultados inesperados na inoculação da leguminosa. Estudou-se a variabilidade nas características fenotípicas e a estabilidade genética das estirpes de Bradyrizobium recomendadas para a inoculação em soja. Foram isolados variantes com morfologia colonial estável das estirpes SEMIA 5080 de Bradyrhizobium japonicum e SEMIA 5019 de B. elkanii. Variantes da estirpe SEMIA 587, obtidas por outro autor, também foram estudadas. As variantes diferiram nas características coloniais, capacidade de nodulação, eficiência na fixação de nitrogênio, e competitividade para formação de nódulos em duas variedades de soja (Jacui 7 e IAS 5). O comportamento simbiótico das variantes diferiu de acordo com as variedades onde foram inoculadas. Somente as variantes 5019 G e 5019 P, originadas da estirpe SEMIA 5019, diferiram quanto ao perfil isoenzimático. Observou-se diferenças na resistência a antibióticos entre as variantes das duas estirpes. Análises relacionando as características simbióticas com morfologia colonial ou resistência a antibióticos não foram conclusivas. A variabilidade em estirpes de rizóbio pode ser um fator importante a ser considerado nos programas de seleção de estirpes e no monitoramento da preservação das culturas bacterianas para a produção de inoculantes.

Palavras-chaves: isolamento de variantes, produção de inoculantes, isoenzymas.

\section{INTRODUCTION}

The rapid reproduction of bacteria allows the abundant appearance of variants in the natural environment or in artificial culture. In cultures of the bacteria of legume symbionts, such as Bradyrhizobium spp., the variations may result in changes of cultural, biochemical or symbiotic characteristics (MEYER \& PUEPPKE, 1980). Routine serological methods cannot differentiate these variants. Variants with superior symbiotic efficiency may also occur (SANTOS, 1999) and this possibility is of interest for the selection of strains and improvement of the quality of legume inoculants (SATO, 1995).

Tests of rhizobiotoxin production (FUHRMANN, 1990), analysis of the polymorphism of restriction fragment length (RFLP) and sequencing of the 16S fraction of rRNA of B. japonicum led to a proposal for the establishment of the new species of B. elkanii (KUYKENDALL et al., 1992). The strains SEMIA 587 and SEMIA 5019 have characteristics of

\footnotetext{
${ }^{1}$ Biologist, MSc, Course of Biology, Universidade Luterana do Brasil, (ULBRA).

2 Engenheiro Agrônomo, Doctor, Department of Soil Science, Universidade Federal do Rio Grande do Sul, (UFRGS), CP 776 90001-970, Porto Alegre, RS, Brazil. E-mail: enilson.sa@ufrgs.br. Corresponding author

${ }^{3}$ Biologist, Master of Science Student, Course of Microbiologia Agrícola e do Ambiente, Department of Soil Science, UFRGS.
} 
this new species (RUMJANEK et al., 1993; LEMOS, 1994), while the strains SEMIA 5080 and SEMIA 5079 have characteristics of $\boldsymbol{B}$. japonicum. These four strains are recommended for the production of soybean inoculants in Brazil.

Some variants in colony morphology may be stable even after several generations, passage in plants, subculture or preservation by lyophilization. Stable variants obtained from strain SEMIA 587, after lyophilization, showed changes in carbohydrate fermentation, resistance to antibiotics and efficiency in N2 fixation, but not in antigenic characteristics and a-esterase profile (SATO, 1995). The differences in colony morphology can be related to the type and amount of exopolisaccharide. Large mucoid (LM) and dry small (SD) colonies would be linked to DNA homology groups I and II, while strains in group III form large gummy colonies (LW) (FUHRMANN, 1990; BASIT et al., 1991).

Resistance to antibiotics may be used to characterize different strains. An interrelationship between colony morphology and resistance to antibiotics was reported (SINCLAIR \& EAGLESHAM, 1984). However, that resistance is a characteristic of each strain or variant (RODRIGUEZ et al., 1987).

Electrophoretic analysis of isoenzymes has been also used to detect changes in aminoacid composition (SELANDER et al., 1986) and thus differentiate between serogroups and detect mutants.

Variations in competitive ability between strains in a multi-strain inoculant or between variants of the same strain in a single strain inoculant could cause problems in rhizobia inoculant quality. FRANKENBERG et al., (1995) found that strain SEMIA 587 out performed strain SEMIA 5019 in growth in culture broth and peat inoculant, in nodulation and in the efficiency of N2 fixation in soybeans. Also, necrosis of the central tissue of nodules induced by some mutants was reported (FERRAIOLI, 2002), an unusual characteristic even in nodules by Fix (-) mutants.

In the selection of strains for legume inoculation the objective is to obtain strains with desirable symbiotic characteristics, including high nitrogen fixation, competitiveness for nodule formation and genetic stability. There are some prospects of using nodulation mutants in developing grain legume cultivars that combine high yield with high residual nitrogen for developing sustainable cropping systems (BHATIA, 2001). The objective of this work was to evaluate the genetic stability of three strains recommended for soybean inoculation.

\section{MATERIALS AND METHODS}

The work was carried out with cultures of Bradyrhizobium japonicum strain SEMIA 5080 and with Bradyrhizobium elkanii strain SEMIA 5019, obtained in lyophilised form from the Culture Collection of Rhizobia of the Foundation of Agriculture Research of Rio Grande do Sul (FEPAGRO), and with variants $587 \mathrm{P} 2$ and 587 P7 of B. elkanii, strain SEMIA 587, obtained by SATO (1995).

Purity tests were carried out by inoculation on nutrient agar, glucose peptone agar and yeast mannitol bromthymol blue agar (YMB) (SOMASEGARAN \& HOBEN, 1994). Successive sub culturing on yeast mannitol Congo red agar (YMCR) was made to obtain variants with colonies of distinct and stable morphology. These were typed by serological agglutination tests (LEMOS, 1994) with hyperimmune sera to the original strains supplied by the FEPAGRO centre.

For antibiotic resistance evaluation of the variants were grown in YMCR and after one week inoculated on plates of the same medium containing streptomycin sulphate, novobiocin $(80,100,200,300$ $\mathrm{mg} / \mathrm{ml})$ and kannamycin $(60,80,100,200 \mathrm{mg} / \mathrm{ml})$. After seven days of incubation at $28^{\circ} \mathrm{C}$, the plates with growth were considered resistant.

Electrophoretic analysis of isoenzymes was performed in the Laboratory of Microbiology UNESP - Jaboticabal. Isolates was grown in $50 \mathrm{ml}$ of tryptoneyeast medium (TY) (ENGVILD \& NIELSEN, 1985) for 72 hours at $28^{\circ} \mathrm{C}$ and 120rpm. After centrifugation $\left(15,000 \mathrm{X} \mathrm{g}, 4^{\circ} \mathrm{C}-20 \mathrm{~min}\right)$, the bacterial pellet was washed several times in saline solution. The cells were suspended and diluted in saline until turbidity of 400 Kletts units and then centrifuged for $5 \mathrm{~min}$ at $12,000 \mathrm{~g}$. The pellet was resuspended in $0.5 \mathrm{ml}$ of extraction buffer, centrifuged for $5 \mathrm{~min}$ and then suspended in extraction buffer plus lysozyme and left for 10min. After, the pellet was resuspended in $0,5 \mathrm{ml}$ of sonification buffer (100ml TRIS-HCL $0,1 \mathrm{M} \mathrm{pH} 8,8$ in $15 \mathrm{~g}$ glycerol) (LEMOS, 1994) and kept on ice to avoid protein denaturation. The cells were disrupted with ultra sound by $10 \mathrm{~min}$ in an ice bath with 10 second pulses, centrifuged for $5 \min (12,000 \mathrm{Xg})$ at $4^{\circ} \mathrm{C}$ and the supernatant collected for electrophoresis in polyacrilamide gel by one hour and $15 \mathrm{~min}$ at $4^{\circ} \mathrm{C}$ and $200 \mathrm{~V}$.

After electrophoresis, the gels were incubated for $30 \mathrm{~min}$ in phosphate buffer $(0,1 \mathrm{M} \mathrm{pH}$ 6,2 ) and stained for esterases and 3-hydroxybutyrate dehydrogenase. Aliquots of $100 \mathrm{ml}$ of phosphate buffer plus $100 \mathrm{mg}$ Fast Blue-RR salt and $60 \mathrm{mg}$ of a- 
naphtylacetate in acetone solution was added to the gel for a-esterase detection. It was stained with phosphate buffer $0.1 \mathrm{M}$, plus 100mg Fast Blue RR salt and 40mg b-naphtylacetate for b-esterase detection. After colour change the gels were washed in a mixture of ethanol, acetic acid and water (PASTEUR et al., 1988). For detection of 3-hydroxybutyrate dehydrogenase the gel was shaked for $15 \mathrm{~min}$ in a solution of $20 \mathrm{ml}$ Tris-HCl with $50 \mathrm{mg}$ D, L-bhydroxybutyrate and $0.5 \mathrm{ml} \mathrm{NAD} 1 \%$. After $15 \mathrm{~min}, 0,5 \mathrm{ml}$ of MTT (3-4, 5-dimethythiazolyl-2-2, 5diphenyltetrazolium bromide) and $0.5 \mathrm{ml}$ of PMS (phenazine methosulphate) were added for the observation of the bands.

The infective capacity, nodulation, nitrogen fixation and competitive ability of the variants were evaluated with the soybean varieties IAS 5 and Jacui 7 inoculated in "growth pouches" and "Leonard" jars (SOMASEGARAN \& HOBEN, 1994). After germination, the seedlings were inoculated with the cultures of variants. To assess competitive ability the variants were mixed in pairs and the nodule occupation was determined by the agglutination method (LEMOS, 1994) in 40 nodules/pot. Stock cultures were not used in the competition experiments because they would be indeed mixtures of variants. The index of relative efficiency $\left(\mathrm{Efr}^{\mathrm{a}}\right)$, which is a result of the total nitrogen of treatments in relation to the nitrogen controls, was determined as indicated by BROCKWELL et al. (1966).

\section{RESULTS AND DISCUSSION}

Based on the colony morphology, two variants, $5080 \mathrm{P}$ and $5080 \mathrm{G}$, were isolated from $\boldsymbol{B}$. japonicum strain SEMIA 5080 and two from B. elkanii strain SEMIA 5019. The variant $5080 \mathrm{P}$ produced punctiform, butirous and translucent colonies, and was markedly distinct from the colony morphology of the strain SEMIA 5080 and from the other variant $5080 \mathrm{G}$ that showed abundant growth and acid production on YMB agar. The variants $5019 \mathrm{P}$ and $5019 \mathrm{G}$ produced colonies strikingly different. The variants of strain SEMIA 587 showed little difference in colony morphology (Table 1).

The variants of strain SEMIA 5080 were susceptible to kanamycin, streptomycin, novobiocin and tetracycline, while those from strain 587 were resistant (Table1). Similar result was obtained by SATO (1995) who showed that B. japonicum strains are less resistant than those of $\boldsymbol{B}$. elkanii, confirmed by the observations of BODDEY \& HUNGRIA (1997). The variant $5019 \mathrm{P}$ showed resistance to novobiocin and tetracycline and was susceptible to kanamycin and streptomycin (Table 1). Colony morphology of variants of B. japonicum was related to the antibiotic resistance (MEYER \& PUEPPKE, 1980). This characteristic seems not be general and was not pointed by other works (MULLEN \& WOLLUN, 1989; SATO, 1995). Intrinsic resistance to antibiotics together with serological analysis are important characteristics that may contribute to the initial selection of a dominant strain with higher survival and competitiveness.

The electrophoretic isoenzyme analysis showed that variants $5080 \mathrm{G}, 5080 \mathrm{P}, 587 \mathrm{P} 2$ and $587 \mathrm{P} 7$ had no polymorphic differences. However, variants $5019 \mathrm{G}$ and $5019 \mathrm{P}$ had completely different profiles, in spite of being of the same serological group. Similar results were observed with spontaneous and induced variants of Bradyrhizobium that varied in the enzymes

Table 1 - Colony characteristics, antibiotic resistance and acid production, of Bradyrhizobium japonicum and $\boldsymbol{B}$. elkanii variants cultured in yeast mannitol agar and yeast mannitol bromthymol blue, after 7 days a $28^{\circ} \mathrm{C}$.

\begin{tabular}{|c|c|c|c|c|c|c|}
\hline \multirow[b]{2}{*}{ Variants } & \multicolumn{6}{|c|}{ Colony characteristics } \\
\hline & Elevation & Consistency & Size $(\mathrm{mm})$ & $\begin{array}{c}\text { Optical } \\
\text { appearance }\end{array}$ & $\begin{array}{l}\text { Antibiotic } \\
\text { resistance * }\end{array}$ & $\begin{array}{c}\text { Acid } \\
\text { production.** }\end{array}$ \\
\hline $5080 \mathrm{G}$ & convex high & gummy & 2,0 & opaque & None & + \\
\hline $5080 \mathrm{P}$ & punctiform & butirous & $<0,5$ & translucent & None & - \\
\hline $5019 \mathrm{G}$ & convex low & gummy & 1,5 & opaque & Kan, Nov & - \\
\hline $5019 \mathrm{P}$ & punctiform & butirous & 0,5 & translucent & Nov, Tet & - \\
\hline $587 \mathrm{P} 2$ & punctiform & aqueous & 0,5 & translucent & Kan, Nov, Tet & - \\
\hline $587 \mathrm{P} 7$ & punctiform & aqueous & $<0,5$ & translucent & Kan, Str, Nov, Tet & - \\
\hline
\end{tabular}

* Resistance of variants to Kan $=$ kanamycin $\left(100 \mu \mathrm{g} \mathrm{ml}^{-1}\right)$, Nov = novobiocin $\left(200 \mu \mathrm{g} \mathrm{ml}^{-1}\right)$, Str $=$ streptomycin $\left(200 \mathrm{e}^{2} 300 \mu \mathrm{g} \mathrm{ml}{ }^{-1}\right), \mathrm{Tet}=$ tetracycline $\left(300 \mu \mathrm{g} \mathrm{ml^{-1 } )}\right.$

** Reaction in YMA bromthymol blue. 
( and (-esterase profiles (KOZUSNY-ANDREANI, 1992). The electrophoretic profiles of $\alpha$ and $\beta$ esterases (Figure 1A and 1B) showed similarity of variants obtained from SEMIA 5080, but those differed from those of SEMIA 587 and SEMIA 5019 strains. These results were also found by LEMOS (1994) who confirmed the four homology groups already defined. The enzymatic polymorphism tests might be an efficient way to characterize strains and establish the genetic structure of rhizobia populations (ENGVILD \& NIELSEN, 1985; ENGVILD et al., 1990). The restricted differences found in this study (only between variants of strain 5019) might be related to the small number of enzymes tested.

The variant $5080 \mathrm{P}$ did not form nodules neither in the soybean variety IAS 5, it just produced two nodules, nor in Jacui 7 (Table 2). All other variants showed adequate, although variable, nodulation and nitrogen fixation. Differences however occurred according to the soybean variety tested. The symbiotic efficiency of the variants, measured by relative efficiency index (Table 2), allows to calculate the relative contribution of the symbiotic nitrogen fixation. The variants $587 \mathrm{P} 7$ and $5019 \mathrm{P}$ had a better performance in Jacui 7, compared to IAS 5. The variant $5080 \mathrm{P}$ was the worst on its incapacity to form nodules. SATO (1995) observed that variants 587 P2 and 587 P7 also showed completely different behaviour in efficiency of N2 fixation. In this study variant 587 P2 formed a large number of nodules in Jacui 7 with no nitrogen fixation, while the variant 587 P7 was highly effective. However, these two variants showed similar nitrogen fixation efficiency in the soybean variety IAS 5 (Table 2), there were clear differences between these variants from the same strain.

In the competition experiment (Table 3) higher capacity for nodule formation was observed with variants $5019 \mathrm{G}$ and $5019 \mathrm{P}$ than the others when inoculated in the soybean variety IAS 5. However, in Jacui 7 the reverse occurred, with 587 P2 and 587 P7 predominating over variants of the strain 5019 . Competitiveness was inherent in strain and expression differed with variety. The high competitive ability of strains SEMIA 587 and SEMIA 5019 had also been observed before in four soybean varieties (PERES \& VIDOR, 1980).

The nitrogen fixation efficiency of the variants separately (Table 2) compared with the results in mixture and the competitive ability in mixtures (Table 3 ) showed that the predominance of a more efficient variant determines the final results of symbiosis. In mixtures with less efficient variants as $5080 \mathrm{P}+587 \mathrm{P} 2$ the result was affected and the lack of infectivity of the variant $5080 \mathrm{P}$ was confirmed in both varieties. In these mixtures of variants $(5080 \mathrm{G}+587 \mathrm{P} 2)$ in spite of the absolute predominance of the variant $587 \mathrm{P} 2$ productiveness in dry matter and total nitrogen of the plants was also low. It is not possible to explain this behaviour.

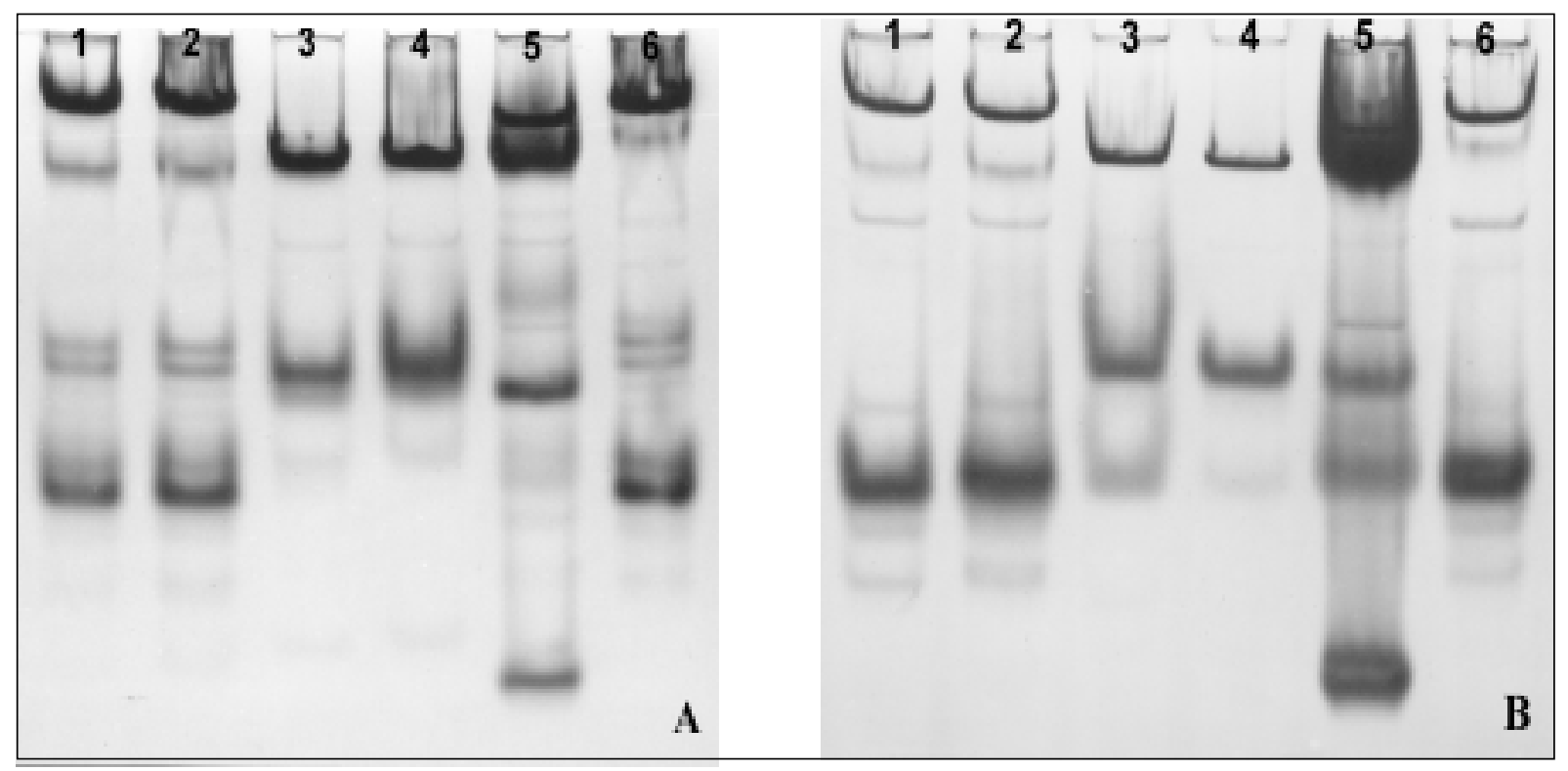

Figure 1- Electrophoretic profile of $\alpha$-esterase (A) and $\beta$-esterase (B) of variants of $\boldsymbol{B}$. japonicum and B. elkanii. Legend: Lane 1 $=587-\mathrm{P} 7$; lane $2=587-\mathrm{P} 2 ;$ lane $3=5080-\mathrm{G}$; lane $4=5080-\mathrm{P} ;$ lane $5=5019-\mathrm{G} ;$ and lane $6=5019 \mathrm{P}$. 
Table 2 - Plant dry matter, number of nodules, relative efficiency index $\left(\right.$ Efr $\left.^{\mathrm{a}}\right)$ and total Nitrogen (Total N) of soybean varieties (JACUI 7 and IAS 5) inoculated with variants of B. japonicum (SEMIA 5080) and B. elkanii (SEMIA 5019 and 587). Averages from five replicates*.

\begin{tabular}{|c|c|c|c|c|c|c|c|c|}
\hline \multirow[b]{2}{*}{ Treatments } & \multicolumn{4}{|c|}{ Jacui 7} & \multicolumn{4}{|c|}{ IAS 5} \\
\hline & Plant dry matter $(\mathrm{g})$ & $\begin{array}{c}\text { Number } \\
\text { of } \\
\text { nodules }\end{array}$ & $\operatorname{Efr}^{\mathrm{a}}(\%)$ & Total N (mg) & $\begin{array}{l}\text { Plant dry } \\
\text { matter } \\
\text { (g) }\end{array}$ & $\begin{array}{c}\text { Number of } \\
\text { nodules }\end{array}$ & $\begin{array}{l}\text { Efr }^{\mathrm{a}} \\
(\%)\end{array}$ & $\begin{array}{c}\text { Total } \\
\text { nitrogen } \\
(\mathrm{mg})\end{array}$ \\
\hline $\mathrm{N}+$ & $6.1 \mathrm{a}$ & 0 & 100 & $63 \mathrm{a}$ & $7.1 \mathrm{a}$ & 0 & 100 & $156 \mathrm{a}$ \\
\hline $\mathrm{N}-$ & $1.6 \mathrm{e}$ & 0 & - & $13 \mathrm{~b}$ & $2.0 \mathrm{~b}$ & 0 & - & $14 \mathrm{~b}$ \\
\hline $5080 \mathrm{G}$ & $2.6 \mathrm{de}$ & $18 \mathrm{~cd}$ & 32 & $29 \mathrm{~b}$ & $7.3 \mathrm{a}$ & $57 \mathrm{ab}$ & 86 & $136 \mathrm{a}$ \\
\hline $5080 \mathrm{P}$ & $2.3 \mathrm{e}$ & 0 & 1 & $13 \mathrm{~b}$ & $1.7 \mathrm{~b}$ & $2 \mathrm{~b}$ & -2 & $12 \mathrm{~b}$ \\
\hline $5019 \mathrm{G}$ & $2.2 \mathrm{e}$ & $22 \mathrm{bcd}$ & 26 & $26 \mathrm{~b}$ & $6.7 \mathrm{a}$ & $107 \mathrm{a}$ & 97 & $150 \mathrm{a}$ \\
\hline $5019 \mathrm{P}$ & $3.9 \mathrm{~cd}$ & $49 \mathrm{ab}$ & 136 & $81 \mathrm{a}$ & $5.9 \mathrm{a}$ & $80 \mathrm{a}$ & 100 & $156 \mathrm{a}$ \\
\hline $587 \mathrm{P} 2$ & $1.5 \mathrm{e}$ & $39 \mathrm{abc}$ & 0 & $13 \mathrm{~b}$ & $4.9 \mathrm{a}$ & $108 \mathrm{a}$ & 53 & $89 \mathrm{ab}$ \\
\hline $587 \mathrm{P} 7$ & $4.2 \mathrm{bc}$ & $67 \mathrm{a}$ & 166 & $96 \mathrm{a}$ & $6.5 \mathrm{a}$ & $81 \mathrm{a}$ & 66 & $108 \mathrm{a}$ \\
\hline
\end{tabular}

* Means followed by the same letter in the column have no significant difference at $5 \%$ by the Tukey test. $\mathrm{N}+=$ control with $\mathrm{NH}_{4} \mathrm{NO}_{3}$ solution $2 \%\left(15 \mathrm{ml}\right.$ pot $\left.^{-1}\right)$.

$\mathrm{N}-=$ control without nitrogen.

Table 3.- Nodule occupancy, plant dry matter, and total Nitrogen (Total N) of soybean varieties (JACUI 7 and IAS 5) inoculated with mixtures of variants of B. japonicum (SEMIA 5080) and B. elkanii (SEMIA 5019 and 587). Averages from five replicates *.

\begin{tabular}{|c|c|c|c|c|c|c|}
\hline \multirow[b]{2}{*}{ Treatments } & \multicolumn{2}{|c|}{ Jacui 7} & \multirow[b]{2}{*}{$\begin{array}{l}\text { Total N } \\
(\mathrm{mg})\end{array}$} & \multicolumn{3}{|c|}{ IAS 5} \\
\hline & $\begin{array}{c}\text { Nodule } \\
\text { Occupancy } \\
(\%)^{* *}\end{array}$ & $\begin{array}{c}\text { Plant } \\
\text { dry matter } \\
\text { (g) }\end{array}$ & & $\begin{array}{c}\begin{array}{c}\text { Nodule } \\
\text { occupancy }\end{array} \\
(\%)^{* *}\end{array}$ & $\begin{array}{l}\text { Plant dry matter } \\
\qquad(\mathrm{g})\end{array}$ & $\begin{array}{c}\text { Total N } \\
\text { (mg) }\end{array}$ \\
\hline $\mathrm{N}+$ & - & $6.1 \mathrm{a}$ & $65 \mathrm{a}$ & - & $7.1 \mathrm{a}$ & $156 \mathrm{a}$ \\
\hline $\mathrm{N}-$ & - & $1.7 \mathrm{~cd}$ & $13 \mathrm{~d}$ & - & $2.0 \mathrm{c}$ & $18 \mathrm{c}$ \\
\hline $5080 \mathrm{G}+5019 \mathrm{G}$ & $(3-27)$ & $1.8 \mathrm{~cd}$ & $10 \mathrm{~d}$ & $(3-95)$ & $5.1 \mathrm{ab}$ & $130 \mathrm{ab}$ \\
\hline $5080 \mathrm{G}+5019 \mathrm{P}$ & $(8-69)$ & $2.2 \mathrm{~cd}$ & $19 \mathrm{~cd}$ & $(8-78)$ & $5.5 \mathrm{ab}$ & $134 \mathrm{ab}$ \\
\hline $5080 \mathrm{G}+587 \mathrm{P} 2$ & $(14-76)$ & $1.8 \mathrm{~cd}$ & $13 \mathrm{~d}$ & $(6-91)$ & $4.3 \mathrm{bc}$ & $98 \mathrm{ab}$ \\
\hline $5080 \mathrm{G}+587 \mathrm{P} 7$ & $(12-85)$ & $2.3 \mathrm{~cd}$ & $25 \mathrm{bcd}$ & $(52-56)$ & $5.1 \mathrm{ab}$ & $136 \mathrm{ab}$ \\
\hline $5080 \mathrm{P}+5019 \mathrm{G}$ & $(0-97)$ & $2.4 \mathrm{~cd}$ & $30 \mathrm{bcd}$ & --- & --- & --- \\
\hline $5080 \mathrm{P}+5019 \mathrm{P}$ & $(0-100)$ & $3.1 \mathrm{~cd}$ & $33 \mathrm{bcd}$ & $(0-95)$ & $4.6 \mathrm{~b}$ & $103 a b$ \\
\hline $5080 \mathrm{P}+587 \mathrm{P} 2$ & $(0-90)$ & $2.0 \mathrm{~cd}$ & $15 \mathrm{~d}$ & $(4-96)$ & $4.2 \mathrm{bc}$ & $101 \mathrm{ab}$ \\
\hline $5080 \mathrm{P}+587 \mathrm{P} 7$ & $(1-94)$ & $2.2 \mathrm{~cd}$ & $26 \mathrm{~d}$ & $(0-100)$ & $5.6 \mathrm{ab}$ & $129 \mathrm{ab}$ \\
\hline $5019 \mathrm{G}+587 \mathrm{P} 2$ & $(15-82)$ & $1.4 \mathrm{~d}$ & $13 \mathrm{~d}$ & $(83-9)$ & $3.3 \mathrm{bc}$ & $65 \mathrm{bc}$ \\
\hline $5019 \mathrm{G}+587 \mathrm{P} 7$ & $(15-83)$ & $3.1 \mathrm{~cd}$ & $60 \mathrm{a}$ & $(67-21)$ & $5.2 \mathrm{ab}$ & $158 \mathrm{a}$ \\
\hline $5019 \mathrm{P}+587 \mathrm{P} 2$ & $(81-15)$ & $2.8 \mathrm{~cd}$ & $42 \mathrm{abc}$ & $(96-4)$ & $4.4 \mathrm{bc}$ & $108 \mathrm{ab}$ \\
\hline $5019 \mathrm{P}+587 \mathrm{P} 7$ & $(72-25)$ & $3.4 \mathrm{bc}$ & $46 \mathrm{ab}$ & $(66-34)$ & $5.0 \mathrm{ab}$ & $131 \mathrm{ab}$ \\
\hline
\end{tabular}

* Means followed by the same letter in the column have no significant difference at $5 \%$ by the Tukey test.

** The differences to 100 in the total nodule occupancy were due to nodules without or with double reaction.

Relationship between colony morphology and nitrogen fixation has been pointed (MEYER \& PUEPPKE 1980; MULLEN \& WOLLUN 1989). However, no consistent correlation was found in this study, consistent with other works (RODRIGUEZ et al., 1987; BASIT et al., 1991 and SATO, 1995).

\section{CONCLUSIONS}

Our results indicate that spontaneous variation in rhizobia strains may occur and the isolation and selection of variants may be possibly based on easily detectable characteristics as stable colony 
morphology and symbiotic behaviour. When spontaneous variation occurred in a rhizobial culture for inoculant production, the resulting mixture with ineffective variants will produce a low quality inoculant. Relationship analysis between symbiotic characteristics and colony morphology or antibiotic resistance wasn't conclusive. The variability in rhizobia strains might be an important factor to be considered in strain selection and preservation of cultures for inoculant production. Stable and efficient variants were obtained from the stock cultures and they may be recommended for inoculant production in the place of the original cultures, if results are confirmed in future experiments.

\section{ACKNOWLEDGEMENTS}

We are grateful to Prof. Eliana Lemos for her assistance in electrophoretic analysis, to the FEPAGRO BNF Centre for the rhizobia cultures and antiserum and to Prof. Christine Gaylarde for language revision.

\section{REFERENCES}

BASIT, H.A. et al. Phenotypic diversity among strains of Bradyrhizobium japonicum belonging to serogroup 110. Applied and Environmental Microbiology, Washington, v.57, p.1570$1572,1991$.

BHATIA, C.R. et al. Mutations affecting nodulation in grain legumes and their potential in sustainable cropping systems. Euphytica, Dordrecht, v.120, n.3, p.415-432, 2001.

BODDEY, L.H.; HUNGRIA, M. Phenotyphic grouping of Brazilian Bradyrhizobium strains which nodulate soybean. Biol Fertil Soils, v.25, p.407-415, 1997.

BROCKWELL, J. et al. Some symbiotic characteristics of rhizobia responsible for spontaneous and effective field nodulation of Lotus hispidus. Australian Journal of Experimental Agricultural and Animal Husbandry, Camberra v.6, p.365-370, 1966.

ENGVILD, K.C.; NIELSEN, G. Strain identification in Rhizobium by starch gel electrophoresis of isoenzymes. Plant and Soil, Dordrecht, v.87, p.251-256, 1985.

ENGVILD, K.C. et al. Parallel variation in isoenzyme and nitrogen fixation markers in a Rhizobium population. Plant and Soil, Dordrecht, v.128, p.283-286, 1990.

FERRAIOLI, S. et al. Auxotrophic mutant strains of $\boldsymbol{R}$. etli feveal new nodule development phenotypes. Molecular plant-microbe interaction, Saint Paul, v.15, p.501-510, 2002 .

FRANKENBERG, C.; FREIRE, J.R.J.; THOMAS, R.W.P. Growth and competition between two strains of $\boldsymbol{B}$. japonicum in broth and in a peat-based inoculant: dinitrogen fixation efficiency and competition for nodulation sites. Journal of the Brazilian Society for Microbiology, São Paulo, v.26, p.211218, 1995.
FUHRMANN, J.J. Symbiotic effectiveness of indigenous soybean Bradyrhizobia as related to serological, morphological, rhizobiotoxine, and hydrogenase phenotypes. Applied and Environmental Microbiology, Washington, v.56, p.224-229, 1990.

KOZUSNY-ANDREANI, D.I. Isolamento e caracterização de populações heterogêneas e mutantes espontâneos de duas estirpes de Bradyrhizobium sp. 1992. 124f. Dissertação (Mestrado em Agronomia) - Curso de Pós-graduação em Agronomia, Universidade de São Paulo.

KUYKENDALL, L.D. et al. Genetic diversity in B. japonicum Jordan 1982 and a proposal for B. elkanii sp. nov. Canadian Journal of Microbiology, Ottawa, v.38, p.501-505, 1992.

LEMOS, E.G.M. Classificação e identificação de bradirrizóbios que nodulam soja por análise de padrões isoenzimáticos, sorologia, morfologia de colônias e atividade de hidrogenase. 1994. 108f. Tese (Livredocência) - Universidade Estadual de São Paulo.

MEYER, M.C.; PUEPPKE, S.G. Differentiation of Rhizobium japonicum strain derivatives by antibiotic sensitivity patterns, lectin binding and utilization of biochemicals. Canadian Journal of Microbiology, Ottawa, v.26, p.606-612, 1980.

MULLEN, M.D.; WOLLUN, A.G. Variation among different cultures of Bradyrhizobium japonicum strains USDA 110 and 122. Canadian Journal of Microbiology, Ottawa, v.35, p.583-588, 1989 .

PERES, J.R.R.; VIDOR, C. Seleção de estirpes de Rhizobium japonicum e competitividade por sítios de infecção nodular em cultivares de soja (Glicine max (L.) MERRIL). Agronomia Sulriograndene, Porto Alegre, v.16, p.205-219, 1980.

RODRIGUEZ, J.J.; FREIRE, J.R.J.; SCHRANK,I. Isolation and characterization of variants of Rhizobium leguminosarum bv. Phaseoli. MIRCEN Journal, Oxford, v.3, p.289-295, 1987.

RUMJANEK, N.G. et al. Common soybean inoculant strains in Brazil are members of B. elkanii. Applied and Environmental Microbiology, Washington, v.59, p.4371-4373, 1993.

SANTOS, M.A.; VARGAS, M.A.; HUNGRIA, M. Characterization of soybean Bradyrhizobium strains adapted to the Brazilian savannas. Microbiological Ecology, Delft, v.30, p.261-272, 1999.

SATO, M.L. Sobrevivência e estabilidade genética da SEMIA 587 de Bradyrhizobium japonicum submetida à liofilização. 1995. 157f. Tese (Doutorado em Ciência do Solo) - Curso de Pós-graduação em Ciência do Solo, Universidade Federal do Rio Grande do Sul.

SELANDER, R.K. et al. Methods of multilocus enzyme electrophoresis for bacterial population genetics and systematics. Applied and Environmental Microbiology, Washington, v.51, p.873-884, 1986.

SINCLAIR, M.J.; EAGLESHAM, A.R.J. Intrinsic antibiotic resistance in relation to colony morphology in three populations of West African cowpea rhizobia. Soil Biology and Biochemistry, Oxford, v.16, p.247-251, 1984.

SOMASEGARAN, P.; HOBEN, H.J. Handbook for Rhizobia. New York: Springer, 1994. 450p. 